\title{
Impact of Islamic Religiosity on Consumers' Attitudes towards Islamic and Conventional ways of Advertisements, Attitude towards Brands and Purchase Intentions
}

\author{
Muhammad Abdullah Khan Niazi ${ }^{1}$, Usman Ghani ${ }^{2}$, Sadia Aziz ${ }^{3}$
}

\begin{abstract}
Religious beliefs can shape the perception, behavior and reaction of a person towards marketing activities. This study aimed to examine the direct effect of Islamic religiosity on consumers' attitudes towards Islamic and conventional advertisements in Pakistan. Moreover, the study has also examined serial mediating effects of consumers' attitudes towards Islamic and conventional ways of advertisements and attitude towards brands between Islamic religiosity and their purchase intentions. Consumers' attitude was explained through the theoretical lens of Value-Expressive theory of attitude. Experimental design was used to examine the relationships. Several statistical tools including Exploratory Factor Analysis (EFA) were used for screening and preparing the data for analysis. Structural Equation Modeling (SEM) with bootstrapping method for mediation was used to examine the mediation effects of consumers' attitudes towards Islamic and conventional ways of advertisements and attitude towards brands. Results of the study showed positive relationship between Islamic religiosity and attitude towards Islamic way of advertisements and negative relationship between Islamic religiosity and conventional way of advertisements. Further, results showed that attitude towards Islamic way of advertisement and attitude towards brands positively mediate the relationship between Islamic religiosity and purchase intention, while these relationships were negative for conventional way of advertisements.
\end{abstract}

Keywords: Islamic religiosity; Islamic way of advertisement; conventional way of advertisement; attitude towards advertisement; attitude towards brand; value-expressive theory.

\section{Introduction}

Religious views can play a significant role in shaping social behavior. Dissimilarities

1 PhD Scholar, Institute of Management Sciences, Peshawar. Email: makniazikhan@yahoo.com 2 Associate Professor, Institute of Management Sciences, Peshawar. Email: usman.ghani@imsciences.edu.pk 3 Assistant Professor, Shaheed Benazir Bhutto Women University, Peshawar Email: sadia_aziz11@yahoo.com

\begin{tabular}{ll} 
ARTICLE HISTORY & \\
9 July, 2018 Submission Received & 8 Dec, 2018 First Review \\
\hline 22 Feb, 2019 Second Review & 22 Mar, 2019 Third Review \\
\hline $30 \mathrm{Mar}, 2019$ Accepted &
\end{tabular}


in religious associations have a tendency to influence the way people live, the selections they make, what they consume and whom they relate with. Hirschman (1983) suggests that the religious links of Catholics, Protestants and Jews considerably shape their approaches towards dancing, journals, restaurants and dogmatic thoughts. There is also a substantial association between religious people and greater concern for moral standards (Wiebe \& Fleck, 1980), being conventional (Barton \& Vaughan, 1976), and retaining more usual attitudes (Wilkes, Burnett, \& Howell, 1986). Religion affects gender roles in a specific society. In Islamic countries, both men and women hide their upper body and upper legs at all times and in the case of women, simply their faces' skin may be exposed (Deng, Jivan, \& Hassan, 1994).

Religion explains the philosophies of life and most of the time it influences the actions and attitudes of its followers. Such religious beliefs and opinions shape the behavior and practices of societies and followers of cultures. Violating religious believes in some societies are not taken as a serious crime but in countries like Saudi Arabia, they enforce Islamic principles and violation may result in serious punishments. Religious values are also considered in trade activities and people are targeted according to their religions. In India, hotels are presenting food for vegetarians and in Middle East, Islamic banking has succeeded on funding mode (Rehman \& Brooks, 1987; Fahy, Smart, Pride, \& Ferrell, 1995; Waller, 1999; Waller \& Fam, 2000). Values of Islamic community are based on the faith, which they use to show in all areas of their lives including religious, communal, political and economic practices. Faith is an inseparable unity and imbued in the Islamic principles.

These principles enlighten such conceptions as "Islamic law" and the "Islamic prestige" and accounts for Islam's substantial emphasis on social life and shared duties. One can easily observe the reflection of Islamic laws in the daily business activities of many Muslims. Recently, many multinational corporations have adapted their marketing and business practices for Muslims segments according to Islamic laws. Among all, obtaining Halal certifications is the most common practice of firms targeting the Muslim segment (Alom \& Haque, 2011; Shafiq, Haque, Abdullah, \& Jan, 2017).

Marketing is a main functional area in the businesses that shows an obvious interface with not only consumers, but also with stakeholders such as the mass media, stockholders, governing agencies, network members, trade relatives, as well as others (Jayawardhena \& Farrell, 2011). From a managerial point of view, marketing is a managerial function and a set of processes for creating, conforming and providing value to consumers and for handling customer relations in ways that help the business and its stakeholders (Kotler \& Keller, 2012). According to this definition, marketers need to provide value to customers and recognize customers' insight. It has been seen that customers realize and assess marketing activities according to their personal 
beliefs and foundation of these beliefs could be their culture, traditions or religion. Marketers have to examine customers' cultural patterns to adapt their marketing activities and the key element, which strengthens these patterns, could be religion (Hirschman, 1983; LaBarbera, 1987; Anand \& Kumar, 1982; Tariq \& Khan, 2017).

Islam is the second most followed religion and there are 50 Muslim-majority countries in the world. About $62 \%$ of the world's Muslims live in the Asia-Pacific region. Indonesia is the largest Muslim country consisting of $12.7 \%$ of the world's Muslim population. It is followed by Pakistan with a population exceeding 200 Million people having $96.28 \%$ of Muslim population which is almost $11.0 \%$ of the Muslim world. Recently marketers have started differentiating their marketing activities according to religious beliefs in Muslim countries. Marketers all over the world find Muslims as an attractive segment and try to target them according to their religious values and hence the idea of marketing according to Islamic practices is emerging (Alom \& Haque, 2011).

After taking guiding principles from Quran, Hadiths[sayings of Prophet Muham$\operatorname{mad}(\mathrm{PBUH})]$, Islamic literature and the interviews conducted from Islamic scholars, the concept of Islamic marketing is stated as, "the understanding of fulfilling the needs of customers through the good behaviors of conveying Halal, wholesome, pure and legal products and services with the common consent of both the seller and buyer for the rationale of achieving material and religious well-being in the world now and in future and making consumers aware of it through the good behavior of marketers and moral advertising" (Bukhari, 2009; Siddiqi, 2008). Along with all promotional activities, the most important activity is advertising. Advertisements are generally developed to inform, persuade and remind audience to buy the advertised brand. To have encouraging influence on audience, one should understand their values and beliefs and religion is the most essential motive of developing these principles and beliefs (Kim, David, \& Zafer, 2004).

Amplification is observed as a type of fraud, whether exaggeration is by sign or by writing a description. Amplification is permissible only when it is clear (Siddiqi, 2008; Zebal, 2018). Kavoossi and Frank (1990), in a study of marketing in the Persian Gulf States, witnessed the absence of overemphasis or overestimation, contrary to many American advertisements. Rather, they distinguished that the significance was on long-lastingness, excellence and the overall trustworthiness of the goods and the supplier. For example, an organization for computer services stated, "Our foundation is superior computer service and not profit." Misleading advertising must be avoided (Rice \& Al- Mossawi, 2002). The saying of Prophet Muhammad (PBUH) is, "...he who cheats is not one of us" (Sahih Muslim, Book 1, Hadith Number 190). The message from this Hadith is that if a trader knows that a flaw exists in some- 
thing being sold, is obliged to reveal it before the transaction. Muslim jurists have identified deception as hiding faults, which are not noticeable by public's eye. The Saudi Arabian respondents in the study by Al- Makaty, Tubergen, Whitlow and Boyd (1996) agreed that the administrators should improve the checking of advertising statements. Religious terms may be used in commercials to assure customers of the Islamic morality of products and services. For example, in a TV commercial, a Saudi investment bank in Egypt used religious terms to demonstrate that it did not deal in any illegal financial products.

This study operationalizes Islamic way of advertisement from two perspectives. First, the sexual appeal in advertisement. In the Islamic way of advertisement, there should be no sexual nudity, suggestiveness and attractiveness. Second, the provision of complete information and knowledge about the product without concealing or exaggerating information in the advertisement. On the other hand, all the advertisements are considered as conventional advertisements, which do not consider Islamic values. Therefore, in an Islamic way of advertisement, brand representor must be dressed and behave according to Islamic guidelines and all required information and knowledge must be provided to the customer (Fam, Waller \& Erdogan, 2004).

All promotion messages that follow the Islamic teachings broadcast good morals, such as women in decent style and clothing, supposing their role as an encouraging input to the family and culture as a whole as opposed to being used as items of sexual want (Rice \& Al- Mossawi, 2002). However, there are some restrictions like dressing in Islam. So the above values should be considered before developing advertisements for Muslims. Nevertheless, the intensity of following religion can be different from person to person, which results in different evaluation criteria of Islamic laws. Some Muslims may have very low tolerance level for sexuality in an advertisement but others may have high (Ahmad, 2018).

Unfortunately, not all the Muslims bother about all Islamic values because of their religious following (Rehman \& Shabbir, 2010). Religiosity is a part of religion. Religiosity is identical with a certain belief or principle. Essoo and Dibb (2004) define religiosity as the religious belief a person practices in his life. Religiosity is the commitment to the religious practices. Sallam and Hanafy (1988) indicate that religiosity has a direct positive relation with the attitude. According to them, if a person is highly religious, then he will have low tolerance level against un-Islamic activities. The level of religiosity develops the intensity of attitude and marketers need to understand that how religiosity affects consumers in evaluating advertisements.

Attitude towards an advertisement is a pre-disposition to react in a positive or negative way to a specific advertising incentive during a certain exposure time 
(Burke \& Edell, 1986). Hence, attitude towards an advertisement is an attitudinal response to the advertisement created at the time of exposure. This reaction to the advertisement may lead to attitude towards the advertised brand (Lutz, 1975). Religion can be an influential moderator in interpreting advertisement messages. It is recommended that a prerequisite for closer investigation from religion perspective should be imposed on any advertisement message. Religious connection plays a substantial role in attitude development and value selections and is particularly linked to questions of why people consume (Akbari, Gholizadeh \& Zomorrodi, 2018).

Adopting Islamic way of advertisement is no more an option for international organizations these days. Muslim market is growing rapidly and it is expected that Muslim population will be a dominant segment in the global market in the next decade (Lipka, 2016).

In such a context, marketer should consider the values of the Muslim consumers and should communicate their brands through appropriate advertising and communication messages, which meet the commitment of ethics as, guided in the Islamic Shariah. Bin-Hasan (2016) has discussed the role of religion in advertising regulation. Subsequently, there was little research conducted in the field of religion and advertising. KoKu (2011) suggests two reasons for this. First, perhaps religion may be sensitive area for research. Second, religious influence is ambiguous. More recently, researchers have paid increasing attention to the relevance of religious principles to business decision-making in general (Bin-Hasan, 2016; Rehman \& Shabbir, 2010). The interest in religion arises from today's emphasis on ethics in business and the continuing growth in globalization. Religion can be a powerful factor in the decoding of advertising messages and suggests the need for closer examination of religion and advertising. Development of attitude based on religion is further explained by using Vale-Expressive theory.

In previous researches, less work has been done on intensity of religiosity and these studies did not explore the relationship between the intensity of religiosity and purchase intention by examining the mediating role of attitudes towards Islamic and conventional ways of advertisements and the resulting attitude towards brands. Moreover, none of the studies made comparison between Islamic and conventional ways of advertisements. Therefore, the objectives of this study are to explore whether:

- Islamic religiosity has positive effect on consumers' attitude towards Islamic way of advertisements

- Islamic religiosity has negative effect on consumers' attitude towards conventional way of advertisements 
- Islamic religiosity has positive effect on consumers' attitude towards brands that are advertised in Islamic way

- Islamic religiosity has negative effect on consumers' attitude towards brands that are advertised in conventional way.

- Attitude towards advertisements and attitude towards brands mediate the relationship between religiosity and purchase intention

\section{Literature Review}

Effect of religion on individuals is well-documented (Hirschman, 1983; LaBarbera, 1987; Anand \& Kumar, 1982; Luqmani, Yavas, \& Quraeshi, 1987; Michell \& Al-Mossawi, 1999) but still very few studies have discussed the idea of marketing according to the Islamic principles. Islam defines all aspects of life including business and marketing based on Islamic law (shariah) derived from the Qur'an and the Sunnah (tradition of the Prophet Mohammed) in addition to the rulings of Muslim scholars (Alserhan, 2011; Charrad, 2001)

According to Özlem (2011), the concern in considering the link between Islam and spending and marketing activities has been growing in recent years. One can trace such deliberation in the formation of expert periodicals, the growing number of research articles issued, the organization of academic seminars and professional workshops and the making of high profile consultancy data. Associated with this, comparatively quick and strong interest is definitely the question of why? Why is there a concern in Islam and advertising and why now? A closer look at the literature recommends that underlying this deliberation is the identification of Muslims as a complete and viable market sector (Tariq \& Khan, 2017).

The Islamic marketing philosophy combines a value-maximization perception with the belief of 'justice' for the broader interests of the humanity. These philosophies show a way to create value and increase the standard of living of individuals through professional pursuits. The Islamic ethical rules guarantee esteem for and the individual independence of, both business and customers. Islamic values state that under no circumstances should marketers exploit their consumers or in any way involve themselves in deceitful activities, fraud or cheating (Saeed, Ahmad \& Mukhtar, 2001).

In addition, only few researchers have studied the relationship between religion and marketing communications. There is no prohibition of advertising in Islam and it permits businesspersons to inform others about the Halal offerings (Al-Makaty et al., 1996). Most of the studies conducted in Saudi Arabia, focused on the religious 
content in the advertisement and found the significant effect of Islamic way of advertisement on consumer behavior (Shyan, Waller, \& Zafer, 2004; Luqmani et al., 1987). According to Michell and Al-Mossawi (1999), the purchasing preferences of Muslim consumers are highly influenced by Islamic guided advertisements. These researches clearly support the relationship between Islamic way of advertisement and consumer attitude. Luqmani et al. (1987) suggest that advertisements with the offensive or conventional content must be approved by the religious authorities.

Islamic marketing is based on specific believes and ideology, so one cannot violate these believes and ideologies of Muslim consumers. Such marketing practices differentiate Islamic way of marketing from other conventional marketing practices. Islamic way of marketing targets Muslim consumers with the Islamic knowledge, resources and tools. It is also presumed that a large segment of Muslim consumers exist which can be targeted, extended and, to a certain level, projected by marketers (Sandikc1 \& Ger, 2010).

Before conceptualizing the definition of Islamic marketing, deficiencies in conventional marketing are discussed. While criticizing the conventional way of advertisements, Muslim scholars argue that conventional advertisements attempt to deceive and manipulate the customers (Saeed et al., 2001). Deception in advertisements is practiced in different forms such as overstating the features of product, misstating the features of the product, using catchy words to attract customers for impulse buying or selling useless products, dramatic presentation of product, excluding drawbacks of product and only highlighting positive aspects of product and attracting through fake contests (Abdullah \& Ismail, 2011; Saeed et al., 2001; Al-Buraey, 2004). According to Alserhan (2011), conventional advertisements present women as a sexual object. Conventional advertisements use sexual appeal to divert the attention of customers from the product and provoke them to purchase the product. Islam prohibits the use of sexual appeal in the advertisements. It asks women to be portrayed modestly, in decent manner, and not suggestive of sexual arousal (Saeed et al., 2001; Al-Buraey, 2004).

So, Islamic marketing suggests the following guidelines:

- Content used in Islamic way of advertisement should not exploit the instincts of customers and should not provoke customer for unachievable desires

- Information provided in the Islamic way of advertisement should be comprehensive, concrete, easy to understand and based on truth and must illuminate all the attributes (both good and bad) of product

- The content of the advertisement should not be haram (nudity and sexual appeal must be avoided) 
- Advertisement must include only Halal products

- It should promote Islamic values and moderation in the same

The above guidelines for Islamic advertisements are derived from the basic principles of Halal and Haram. Islamic sharia differentiates Halal and Haram in a clear and comprehensive manner. These principles are consistent and equally endorsed by the Quran, the sayings of the Prophet (PBUH), and Islamic scholars.

According to Nasr (2009), Muslims all over the world share the same believes and rituals and these Islamic believes shape their liking and disliking in the daily life. For example, alcohol is prohibited in Islam, so Muslims do not use alcohol where ever they live or belong from. Adas (2006) has found that Muslim consumers prefer the brand that respect their religious believes and vice versa. Due to diverse segments and diverse buying behaviors, the Muslim segment is now being focused by almost all international brands. That is the reason that food companies have now launched the HALAL version of brands. Islamic marketing does not collaborate or merge their marketing practices with the traditional or conventional marketing; rather it is a unique and differentiated concept (Ahmad, 2018; Zebal, 2018).

To understand the complex relationship between Islamic religiosity and attitude, value-expressive function of Functional Attitude Theory is considered. According to value expressive function theory, consumers develop their consumption attitude to express their cultural, social and religious values. David Katz introduced the Functional Theory of Attitudes in 1960s. This theory suggests that attitudes are classified by the psychological needs and serve particular functions. These functions include maintaining self-esteem, attaining awards, avoiding punishments and performing consumer responses such as product evaluations (Katz, 1960). This theory presumes that individuals' needs are met when they hold a specific positive or negative attitude (Debono, 1987).

Attitudes also can serve important social functions, playing roles in both self-expression and social interaction. These functions include self-expression (identified by a value-expressive function) or self-presentation and public image (identified as a social adjustive function) (Wilcox, 2009). According to Value-Expressive attitude function, customers purchase a product to express their personal believes and values (Shavitt, 1989). Value-Expressive attitude function is designed to predict consumer behavior variables such as product (brand or store) attitude, intention, behavior and loyalty.

Michell and Al-Mossawi's (1999) findings showed that the Muslims with high religiosity do not like the conventional advertisement with the exaggeration and sexuality content while Muslims with low religious believes, enjoy watching conven- 
tional advertisements. There are variations of religiosity level among the Muslims and this diversity can be observed in their purchasing patterns. The reaction of Muslim consumers against unethical content like nudity in the advertisement might be different; one group may like the advertisement while other may dislike it. Suffice to say, that level of religious attitude creates positive or negative preferences against the promotion (Gardner, 1985).

Michell and Al-Mossawi (1999) state that strength of religious beliefs positively affects approach and passion of religious beliefs and is measured by the intensity of religiosity. Religiosity is considered as one of the important parts of social life and an influence on the behavior of the person (Essoo \& Dibb, 2004). The level of religiosity influences the liking and disliking of the person and in commercial perspective, religiosity influences the liking and disliking of consumer towards the brand.

Thyne, Lawson and Todd (2006) argue that people are more lenient to others who relate themselves to the communal and cultural values. To support this argument, several studies have shown that more religious people get influenced easily with whom they relate themselves (Guiso, Sapienza, \& Zingales, 2003; Zamani \& Musa, 2012).Essoo and Dibb (2004) found that religiosity has positive relationship with the purchase intention.

Allport (1966) conceptualized internal and external dimensions of the religiosity. Internal dimension of religiosity affect the thinking and personality of the person while external dimension affects the behaviors and actions of the person. Staudenmayer and Berkman (2006) discussed that religiosity helps in developing the attitude of the consumers. Still research is needed to investigate the effect of religiosity on assessment of advertisements. Lutz (1975) discussed that a person's beliefs play essential role in developing thoughts. Positive or negative assessment of an event depends on beliefs that persons hold and religion plays crucial role in developing those beliefs.

\section{Theoretical Framework and Hypotheses}

Based on the literature review, it can be seen that religion provides guideline and helps consumers in making purchase decisions. Many researchers have identified the significant role of religiosity on consumer attitude towards marketing activities including advertisement, brand and purchase intention (Shin, Park, Moon, \& Kim, 2010). Messages against the religious values and believes are considered unacceptable for the consumers having high religiosity and they show strong negative attitude towards these advertisements and the advertised brands (LaTour \& Henthorne, 1994; Simpson et al., 1998).

Belch and Belch (2004) argued that attitude towards advertisement and attitude 
towards brand have significant effect on purchase intention of consumer. Goldsmith, Lafferty, and Newell (2000) found that religiosity has indirect effect on purchase intention through attitude towards the advertisement. They further argued that consumers develop favorable or unfavorable purchase intention of brand based on their evaluation of advertisement and religious believes of consumers play vital role in that evaluation of advertisement. Consumer with the positive attitude towards advertisement leads to positive attitude towards brand and this relationship completes with the purchase intention. Previous research on religiosity and advertising effectiveness reveal that Islamic religiosity produced more positive attitudes towards Islamic way of advertising and greater purchase intentions than a conventional.

The theoretical framework of the study is presented in Figure 1.Islamic religiosity serves as the independent variable whereas purchase intention serves as the dependent variable. Attitude towards the advertisements and attitude towards the brand mediate the relationship between the independent and dependent variables.

The following hypotheses are drawn from the theoretical framework:

H1a: Islamic religiosity positively affects consumers' attitude towards Islamic way of advertisements.

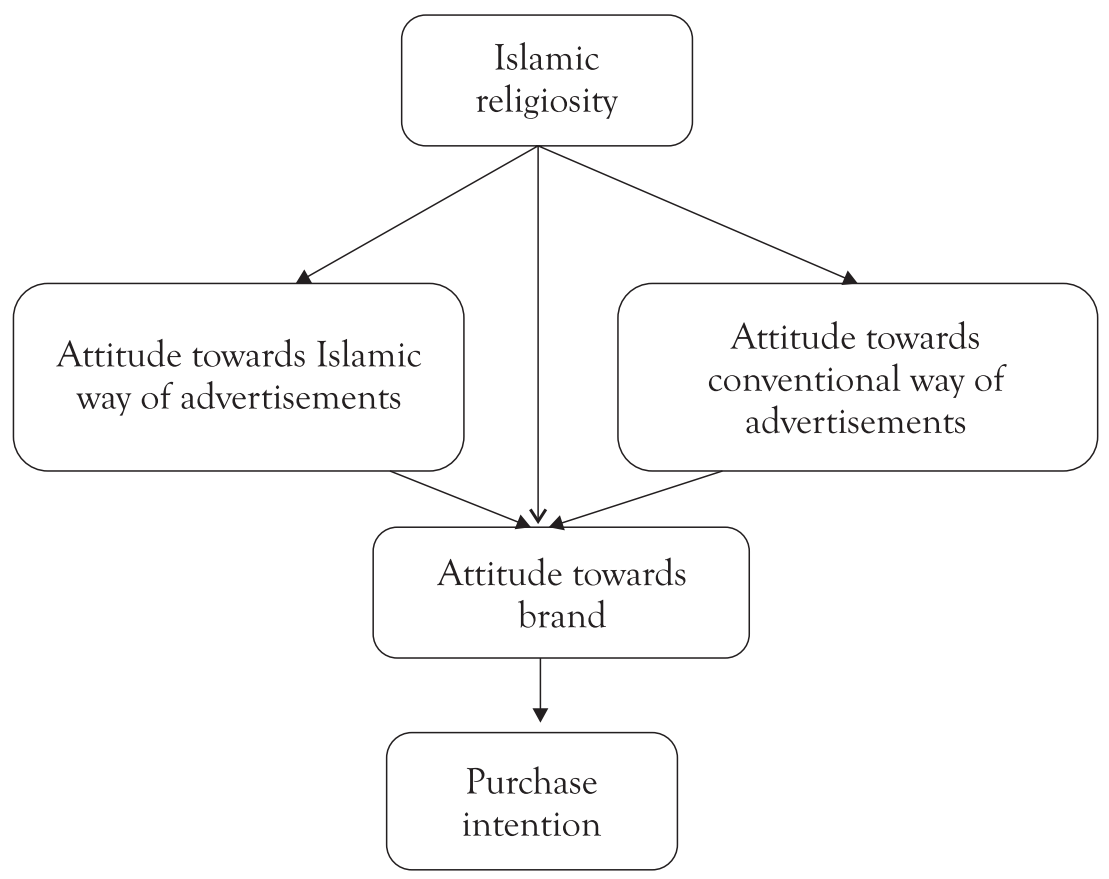

Figure 1: Theoretical Framework 
H1b: Islamic religiosity positively affects consumers' attitude towards brands that are advertised in Islamic way.

H2a: Islamic religiosity negatively affects consumers' attitude towards conventional way of advertisements.

$\mathrm{H} 2 \mathrm{~b}$ : Islamic religiosity negatively affects consumers' attitude towards brands that are advertised in conventional way.

H3: Attitude towards Islamic way of advertisement mediates the positive relationship between Islamic religiosity and attitude towards brand.

H4: Attitude towards conventional advertisement mediates the negative relationship between Islamic religiosity and attitude towards brand.

H5: Attitude towards the Islamic way of advertisement and the resulting attitude towards the brand mediate the positive relationship between Islamic religiosity and purchase intention.

H6: Attitude towards the conventional advertisement and the resulting attitude towards the brand mediate the negative relationship between Islamic religiosity and purchase intention

\section{Methodology}

To test the hypotheses, quantitative research design was adopted and further experimental method was used to examine the direct and indirect effect through using Structural Equation Modeling (SEM). Respondents were asked to fill questionnaires after watching the advertisements. Detail discussion on the sampling and experimental procedure is given below.

\subsection{Sample}

This study was conducted in Peshawar, the capital city of Khyber Pakhtunkhwa province of Pakistan. A total of 210 male and female registered students from different universities (both public and private universities) participated in the experiment. As students were from different degree programs, that is, 4 year Bachelor, MS and $\mathrm{PhD}$, the sample comprised of different age groups, social classes and gender. Multi-Stage probability sampling technique was used to select the final sample. In the first stage, three universities through simple random sampling were selected. In the second step, lists of all registered students from each selected university were taken and in the third step, from the provided list, equal number of students from each university was randomly selected for participation in the experiment. Several marketing researchers 
have adopted the same criteria for experimental design. They have suggested a minimum of 130 participants for an experimental design and they have also used samples of university students to conduct experimental research (Burke \& Edell, 1989; Edell \& Burke, 1987; Holbrook \& Batra, 1987; Jungyeon, 2017). Moreover, this sample is diverse in age, religious association, income level, social status and location. So this sample could provide more generalized results.

\subsection{Selection of advertisements and brands for experiment}

A group of university teachers of marketing and Islamic scholars was asked to select TV advertisements of toothpaste and face wash with unfamiliar brand names. They categorized TV advertisement as Islamic or conventional according to their content, authenticity of claims made in TV advertisements, dressing of models and facts provided to support the claims. Soap and face wash were selected because the sample was diverse in terms of gender, income, social class and status. These products are commonly purchased and used by all age groups, genders and social classes. All selected advertisements were grouped into Islamic and conventional way of advertisements. Islamic way of advertisements had no sexual appeal (nudity, sexual attractiveness and suggestiveness) and are informative. However, conventional advertisements contained content including sexual appeal, deception etc.

\subsection{Experiment procedure}

The experiment was conducted in theatre-like arrangement and it was made sure that participants do not influence each other's responses. For this purpose, experiment was conducted in the main auditoriums of the universities. The researchers themselves administrated the experiment. The experiment was conducted in two steps. In the first step, advertisements (conventional and Islamic) were shown to the respondents. In the second step, after watching the advertisements, each respondent was given a questionnaire.

\subsection{Stimulus manipulation for unbiased experiment}

The focus of this research was to identify the effect of religiosity on consumers' evaluation of advertisements, therefore, extreme care was taken to control for all such factors, which might have created biasness. For example, brand familiarity may heavily influence and overshadow the content (Islamic or conventional) factor in evaluation of advertisements. For this purpose, services of experienced video editors were used who were in the commercial video editing field for more than 8 years. Imaginary brand name such as "Facia" was used for the Face wash advertisement. The brand did not exist in the market and therefore was unfamiliar for the respondents. Other identities 
and associations such as celebrities, logos, brand characters, packaging, color, music and theme songs were also manipulated to avoid any biasness.

\subsection{Data collection instrument}

Questionnaire was used to collect the data. The responses were collected on five points Likert scale [Strongly Disagree (1), Disagree (2), Neutral (3), Agree (4) and Strongly Agree (5)].The respondents' religiosity was measured through eleven items adopted from Sallam and Hanafy (1988). The items were faithfulness on religion, faith on myself, understanding meaning of life, religion's purpose of life, religion as a meaning of life, religion's influence on decision, praying five times a day, reciting Holy Quran, faith as a source of relief, financial contribution to religious organizations and enjoying participating in Islam.

Attitude towards advertisement was measured with the help of four items suggested by Machleit and Wilson (1988). The items were attractive, appealing, good and pleasant. Attitude towards brand was measured with three items including: favorable, positive and good adopted from Batraand Ray (1986).

To measure purchase intention, two items including: 1) on next visit to shop, I will purchase that brand and2) planning to purchase brand in future, were adopted from Grossman and Till (1998). The responses were collected on five points Likert scale

\subsubsection{Instrument reliability and validity}

Internal consistency for measuring reliability was used and Cronbach's alpha values were calculated for each construct (see Appendix 1). Results show that all values are above benchmark value of 0.60 suggested by Hair et al. (1998)

Exploratory factor analysis was used to conduct construct validity (Deshpande, 1982). The Exploratory Factor Analysis was carried out with principal component factor analysis to investigate the validity of religiosity, attitude towards advertisement, attitude towards brand and purchase intention. Results of convergent validity are presented in Appendix 2. The benchmark value for retaining the item was .05 and all values were above .05 (Yong \& Pearce, 2013). Whereas, the results of factor correlational matrix to obtain discriminant validity are presented in Appendix 3.

\subsection{Statistical tool}

SEM technique was used and further a maximum likelihood estimation procedure was considered in AMOS. SEM can be used when a mediating variable is treated in both dependent and independent (serial mediation) way. SEM is used to test the 
models and explain the significance of relationship among the variables.

\section{Results and Analysis}

\subsection{Islamic and conventional advertisement}

All the advertisements were shown to the respondents and they were asked to rate these based on sexual appeal and provision of information level on five points Likert scale. Table1 presents the mean values for each advertisement. A total of 210 questionnaires were distributed. Out of these, 68 were filled by the female and the remaining 142 were filled by the male. All questionnaires were complete and were considered for analysis purpose. From the Table 1, it can be seen that each product category had two types of advertisements, the Islamic and conventional. In the toothpaste category, advertisement of Crest brand is considered conventional way of advertisement with low total mean of information provided in advertisement $(\mathrm{M}=1.68)$. On the other hand, advertisement of Mumin is considered as Islamic way of advertisement having high mean value of information provided in advertisement $(M=3.89)$. Results also show that both conventional and Islamic ways of advertisements for toothpaste category are significantly different $(\mathrm{p}=0.00)$.

While in face wash category, advertisement of Facia brand is considered as conventional way of advertisement with high total mean of sexual appeal in advertisement $(M=4.24)$. On the other hand, advertisement of Valinta is considered as Islamic way of advertisement having low mean value of sexual appeal in advertisement $(M=1.59)$. Results also show that both conventional and Islamic ways of advertisements for face wash category are significantly different $(\mathrm{p}=0.00)$.

\subsection{Hypotheses testing}

Two separate models of SEM were used to test the hypotheses. Before conducting SEM analysis, the following basic assumptions were checked:

Table 1: Mean Comparison of Sexual Appeal and Information Provided in Advertisements

\begin{tabular}{|c|c|c|c|c|c|}
\hline $\begin{array}{c}\text { Advertise- } \\
\text { ment category }\end{array}$ & Advertisement content & Brands & Mean values & N & Sig \\
\hline $\begin{array}{c}\text { Toothpaste ad- } \\
\text { vertisements }\end{array}$ & Information provided & Crest(conventional) & 1.68 & 210 & .000 \\
\cline { 2 - 5 } & Mumin (Islamic) & 3.89 & 210 & \\
\hline $\begin{array}{c}\text { Face wash ad- } \\
\text { vertisements }\end{array}$ & Sexual appeal & Facia(conventional) & 4.24 & 210 & .000 \\
\hline
\end{tabular}




\subsubsection{Test for heteroscedasticity and multicollinearity}

A heteroscedasticity problem occurs when variance is not constant for all observations (Maddala, 1992). The $\mathrm{P}$ value of the White test must be greater than 0.05 . The results of White's Test for Heteroscedasticity showed that the significance value was greater than .05 so there was no issue of heteroscedasticity.

Variance Inflation Factor (VIF) is used to check the multicollinearity problem among the independent variables in the data. The value for VIF must be less than 10. Results in Table 2 clearly indicate that all values of the VIF test are below 10 (Neuman, 2003).

\subsubsection{Structural equation modeling (SEM)}

SEM was used to test the models and explain the significance of relationship among the variables. Initially CFA (Confirmatory Factor Analysis) results showed

Table 2: Assumptions for Structural Equation Modeling

\begin{tabular}{|c|c|c|c|}
\hline $\begin{array}{c}\text { Islamic way of adver- } \\
\text { tisement }\end{array}$ & VIF & \multicolumn{2}{|c|}{ White's Test for Heteroscedasticity } \\
\cline { 2 - 2 } & 1.553 & Chi2 & P-Value \\
\hline $\begin{array}{c}\text { Attitude towards } \\
\text { advertisement }\end{array}$ & 1.761 & \multirow{2}{*}{9.72} & 0.07 \\
\hline $\begin{array}{c}\text { Attitude towards } \\
\text { brand }\end{array}$ & 2.455 & & \\
\hline Purchase intention & & & \\
\hline
\end{tabular}

that the model fits the data reasonably: $\chi^{2}=452, \mathrm{IFI}=0.91$, TLI $=0.99, \mathrm{CFI}=0.93$ and RMSEA $=0.061$. Further separate models were tested for Islamic and conventional advertisements.

\subsubsection{Model-1 specification}

Before interpreting the results of path analysis, specification of Model-1 as shown in Figure 2 is considered to check the appropriateness of model (Hoyle, 1995). Benchmark values along with model values are presented in Table 3.

The proposed structural model was tested using SEM with the maximum likelihood estimation (AMOS 17.0). The results in Table 3 demonstrated the model fit to be acceptable: $\chi^{2}=1.758$; NFI=0.986; IFI $=0.935$; CFI $=0.964$; TLI==0.995; GFI= 0.911; RMSEA $=0.0529$. Path diagram of analyzed model is presented in Figure 2: 


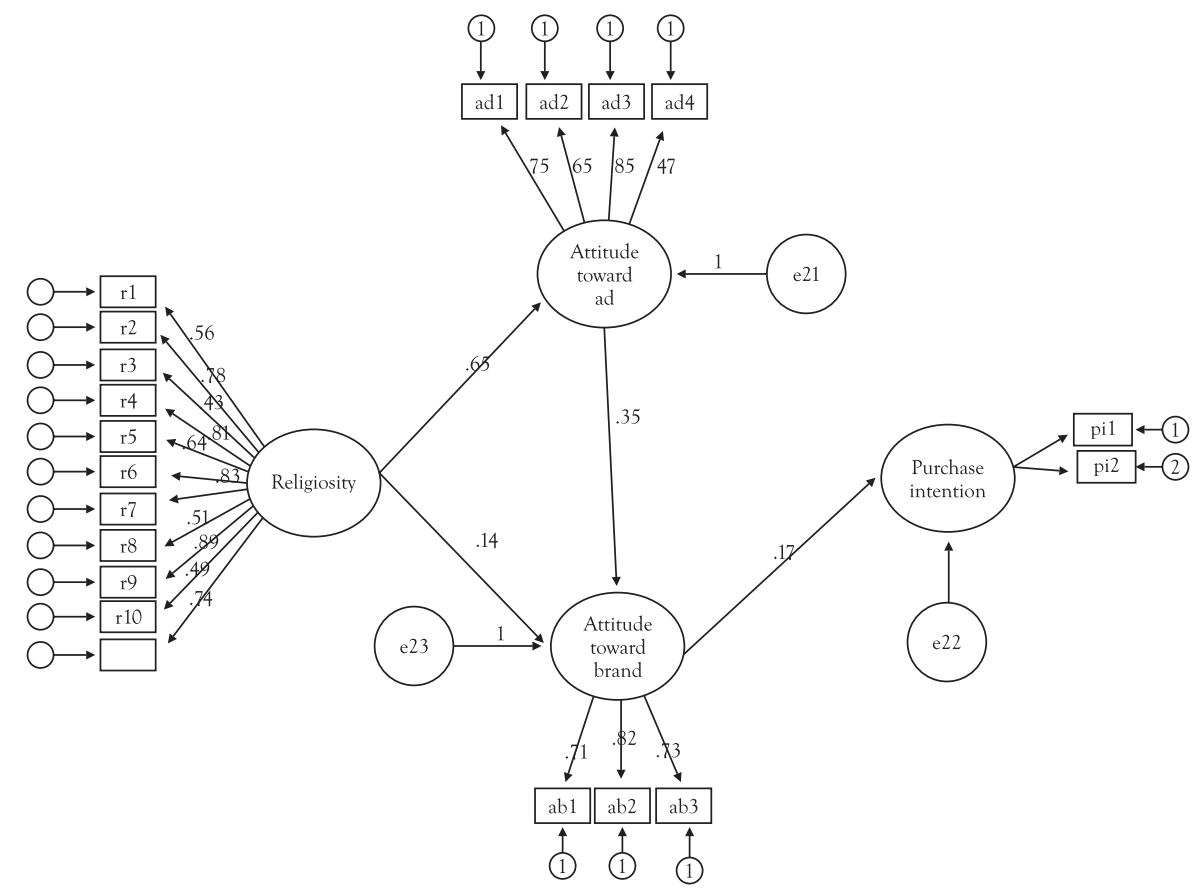

Religiosity= Islamic religiosity ATTIAD= Attitude towards advertisement, ATTIBRAND $=$ Attitude towards brand Purchase $=$ Purchase intention

Figure 2: Path Diagram of Effect of Religiosity on Attitude towards Islamic Way of Advertisement, Brand and Purchase Intention

\subsubsection{Path analysis for model-1}

The results in Table 4 show that religiosity has significant positive effect on the

Table 3: Results of Fit Indices of Model-1

\begin{tabular}{|c|c|c|}
\hline Fit Indices & Measurement Model & Desirable Range \\
\hline$\chi 2(\mathrm{df})$ & 1.758 & $>3.0$ \\
\hline NFI & 0.986 & $<0.9$ \\
\hline IFI & 0.935 & $<0.9$ \\
\hline CFI & 0.964 & $<0.9$ \\
\hline TLI & 0.995 & $<0.9$ \\
\hline GFI & 0.911 & $<0.9$ \\
\hline RMSEA & 0.0529 & $>0.08$ \\
\hline
\end{tabular}

attitude towards Islamic way of advertisement $(\beta=.66, p=0.00)$ and hence hypothesis $\mathrm{H} 1 \mathrm{a}$ that Islamic religiosity positively affect consumers' attitude towards Islamic way 
of advertisements is accepted. Results show significant positive effect of religiosity on Islamic way of advertised brand $(\beta=.14, p=0.008)$. So based on the results, H1b (Islamic religiosity positively affect consumers' attitude towards brands that are advertised in Islamic way) is accepted.

Table 4: Effect of Religiosity on Attitude towards Islamic Way of Advertisement, Brand and Purchase Intention

\begin{tabular}{|c|c|c|c|c|c|c|}
\hline Relationship path & Hypothesis & Direction of & \multicolumn{2}{|c|}{ Direct effect } & \multicolumn{2}{|c|}{ Mediation effect } \\
\cline { 4 - 7 } & relationship & $\beta$ & P-Value & B & P-Value \\
\hline $\begin{array}{c}\text { Religiosity } \rightarrow \text { Attitude } \\
\text { towards Ad }\end{array}$ & $\begin{array}{c}\text { H1a (Accept- } \\
\text { ed) }\end{array}$ & Positive & .66 & .000 & & \\
\hline $\begin{array}{c}\text { Religiosity } \rightarrow \text { Attitude } \\
\text { towards brand }\end{array}$ & $\begin{array}{c}\text { H1b (Accept- } \\
\text { ed) }\end{array}$ & Positive & .14 & .008 & & .000 \\
\hline $\begin{array}{c}\text { Religiosity } \rightarrow \text { Attitude } \\
\text { towards Ad-m } \rightarrow \text { Atti- } \\
\text { tude towards brand }\end{array}$ & H3 (Accepted) & Positive & & & .355 & .001 \\
\hline $\begin{array}{c}\text { Religiosity } \rightarrow \text { Attitude } \\
\text { towards Ad- } \rightarrow \text { Atti- } \\
\text { tude towards brand- } \\
\rightarrow \text { Purchase intention }\end{array}$ & H5 (Accepted) & Positive & & & .179 & \\
\hline
\end{tabular}

Results in Table 4 also show that attitude towards advertisement has significantly mediated the positive relationship between religiosity and attitude towards brand $(\beta=.355, p=0.00)$. So our hypothesis H3 (Attitude towards Islamic way of advertisement mediates the positive relationship between Islamic religiosity and attitude towards brand) is accepted. Results for mediation show that attitude towards Islamic way of advertisement and attitude towards brand has significantly mediated a positive relationship between religiosity and purchase intention $(\beta=.179, p=0.001)$. So our hypothesis H5 (Attitude towards Islamic way of advertisement and attitude towards brand mediates the positive relationship between Islamic religiosity and purchase intention) is accepted.

\subsubsection{Model-2 specification}

Before interpreting the results of path analysis, specification of Model-2 as shown in Figure 3 is considered to check the appropriateness of model (Hoyle, 1995). Benchmark values along with model values are presented in Table 5.

The proposed structural model was tested using SEM with the maximum likelihood estimation (AMOS 17.0). The results demonstrated the model fit to be acceptable 


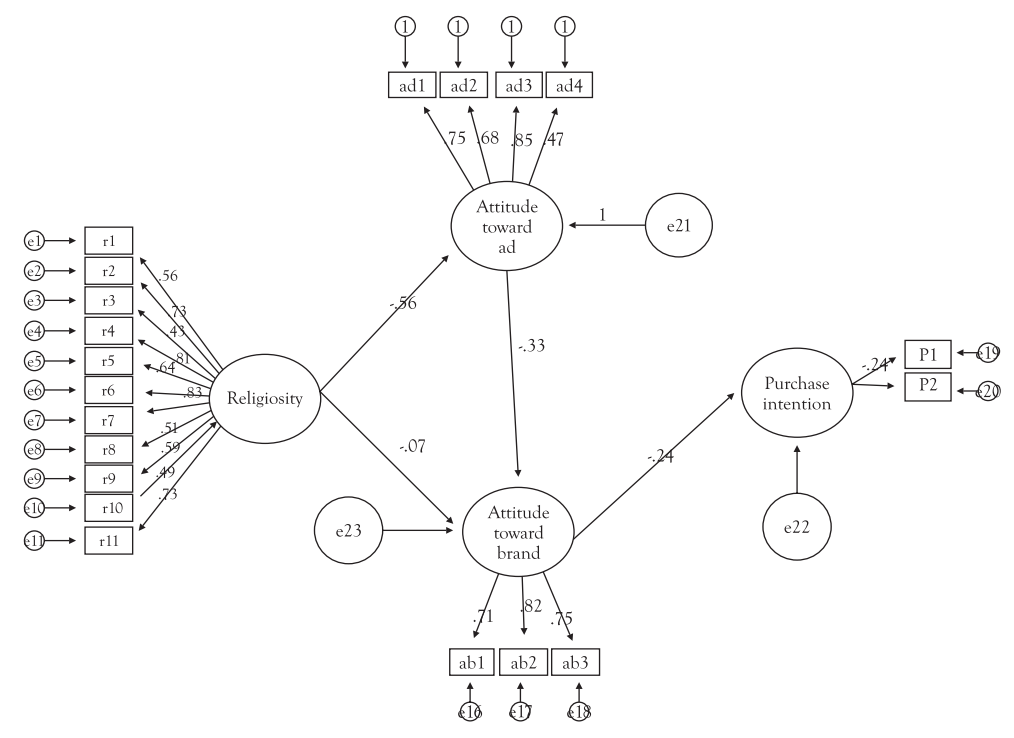

Religiosity= Islamic religiosity ATTIAD= Attitude towards advertisement, ATTIBRAND $=$ Attitude towards brand Purchase $=$ Purchase intention

Figure 3: Path Diagram of Effect of Religiosity on Attitude towards Conventional Advertisement, Brand and Purchase Intention

and path diagram is presented in figure: $\chi^{2}=2.015$; NFI=0.925; IFI $=0.916$; CFI $=$ $0.953 ;$ TLI $=0.919 ; \mathrm{GFI}=0.947 ; \mathrm{RMSEA}=0.0629$.

Table 5: Results of Fit Indices of Proposed Model-2

\begin{tabular}{|c|c|c|}
\hline Fit indices & Measurement model & Desirable range \\
\hline$\chi 2(\mathrm{df})$ & 2.015 & $>3.0$ \\
\hline NFI & 0.925 & $<0.9$ \\
\hline IFI & 0.916 & $<0.9$ \\
\hline CFI & 0.953 & $<0.9$ \\
\hline TLI & 0.919 & $<0.9$ \\
\hline GFI & 0.947 & $<0.9$ \\
\hline RMSEA & 0.0629 & $>0.08$ \\
\hline
\end{tabular}

5.2.6. Path analysis for model-2

The results in Table 6 show that religiosity has significant negative effect on the attitude towards conventional way of advertisement $(\beta=-.564, p=0.005)$ and hence hypothesis $\mathrm{H} 2 \mathrm{a}$ (Islamic religiosity negatively affect consumers' attitude towards conventional way of advertisements) is accepted. Results show insignificant effect of 
Table 6: Effect of Religiosity on Attitude towards Conventional Way of Advertisement, Attitude towards Brand and Purchase Intention

\begin{tabular}{|c|c|c|c|c|c|c|}
\hline Relationship path & Hypothesis & Direction of & \multicolumn{2}{|c|}{ Direct effect } & \multicolumn{2}{|c|}{ Mediation effect } \\
\cline { 4 - 7 } & & relationship & $\beta$ & P-Value & B & P-Value \\
\hline $\begin{array}{c}\text { Religiosity } \rightarrow \text { Attitude } \\
\text { towards Ad }\end{array}$ & $\begin{array}{c}\text { H2a: (accept- } \\
\text { ed) }\end{array}$ & Negative & -.564 & .005 & & \\
\hline $\begin{array}{c}\text { Religiosity } \rightarrow \text { Attitude } \\
\text { towards brand }\end{array}$ & H2b: (rejected) & Negative & -.071 & .080 & & \\
\hline $\begin{array}{c}\text { Religiosity } \rightarrow \text { Attitude } \\
\text { towards Ad } \rightarrow \text { Atti- } \\
\text { tude towards brand }\end{array}$ & H4: (accepted) & Negative & & &. .564 & .005 \\
\hline $\begin{array}{c}\text { Religiosity } \rightarrow \text { Attitude } \\
\text { towards Ad- } \rightarrow \text { Atti- } \\
\text { tude towards brand- } \\
\rightarrow \text { Purchase intention }\end{array}$ & H6: (accepted) & Negative & & &. .071 & .080 \\
\hline
\end{tabular}

religiosity on conventional way of advertised brand $(\beta=-.071, p=.080)$. So based on the results, $\mathrm{H} 2 \mathrm{~b}$ (Islamic religiosity negatively affect consumers' attitude towards brands that are advertised in conventional way) is rejected.

Results in Table 6 also show that attitude towards advertisement has significantly mediated a negative relationship between religiosity and attitude towards brand $(\beta=$,

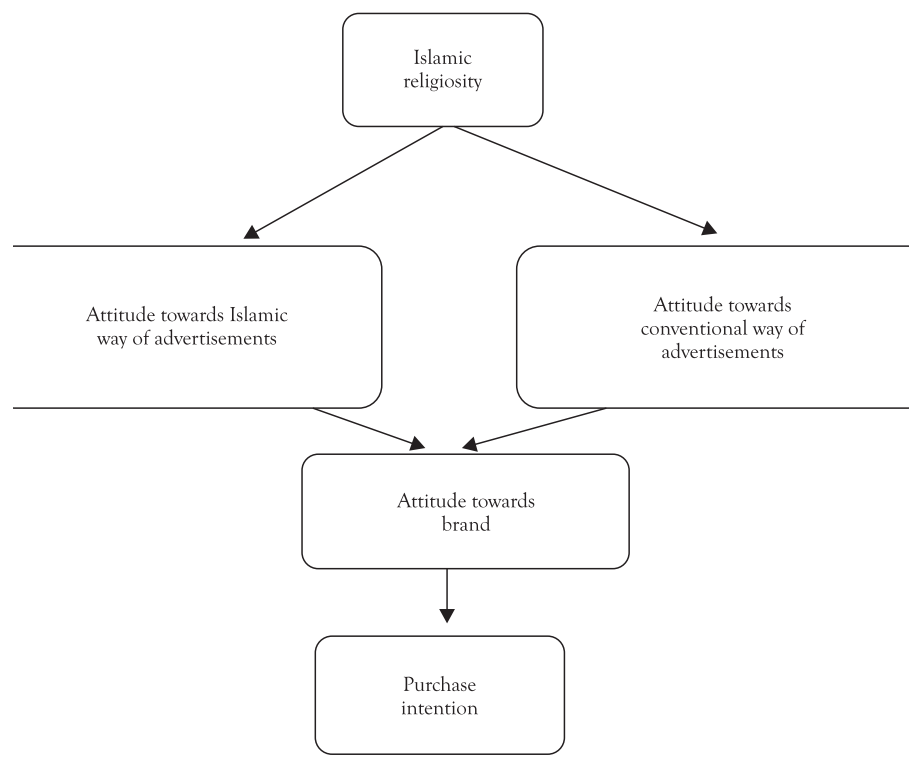

Figure 4: Empirically Tested Model 
$.339, \mathrm{p}=0.00$ ). So our hypothesis H4 (Attitude towards conventional advertisement mediates the negative relationship between Islamic religiosity and attitude towards brand) is accepted. Results for mediation show that attitude towards advertisement and attitude towards brand has significantly mediated a negative relationship between religiosity and purchase intention $(\beta=-.240, p=0.015)$. So our hypothesis H6 (Attitude towards conventional advertisement and attitude towards brand mediates the negative relationship between Islamic religiosity and purchase intention) is accepted. So based on above results, tested model is given below.

\section{Discussion and Conclusion}

Results of path analysis show that there is significant positive relationship between Islamic religiosity and attitude towards Islamic way of advertisements. Results are consistent with the findings of Samir (2012). Further, positive attitude towards Islamic way of advertisements leads to Islamic way of advertised brand positively and finally that positive attitude towards Islamic way of advertised brand leads to purchase intention. These findings are consistent with the study of Shyan et al. (2004) but the dimension of Islamic way of advertisement was not explored in previous researches. These results are clearly supporting value-expressive theory. Hence, religious consumers express their personal values by developing positive attitude towards marketing activities that follow values of religion.

On the other hand, results of the study found significantly negative relationship between Islamic religiosity and attitude towards conventional way of advertisements. This negative relation was revealed in attitude towards brand and purchase intention. Further, results show insignificant effect of religiosity on conventional way of advertised brand. These findings are consistent with the Michell and Al-Mossawi's (1999) study, according to whom culture and religion play vital role during evaluation of advertisements. The insignificant relationship between religiosity and attitude towards conventional way of advertised brand clearly shows that religious beliefs of consumer help in evaluation of advertisements. As, conventional advertisements used in the experiment were not based on Islamic values and were having sexual content, deception and music in advertisement, therefore religious consumer did not consider these advertised brand as attractive.

Based on the significant positive results for Islamic way of advertisements, we suggest that marketer should not use sexual content and deception in advertisements for the Muslim consumers. According to the findings of study, majority of Muslims do have strong religiosity, which restricts them from watching sexual content and they also dislike deception and concealing of information in advertisements. Khraim (2010) also endorses the same construct of religiosity. International advertisers must take 
careful considerations when they plan to adopt sexual appeal in their advertisements for Muslim consumers in Pakistan.

Value-expression theory predicts the behavior of consumers based on their religious beliefs. Results of the study also confirm the attitude theory of value-expression. Religious people express their religious values through their consumption patterns and they negatively express their attitude towards non-Islamic activities. So this theory can predict the consumption patterns of consumers based on their religious beliefs.

Before launching an advertisement, marketers should analyze the content of the advertisement and must design the campaign according to the preferences of the Muslim consumers in Pakistan. Muslims do not accept sexuality in any form because of their religious beliefs, which does not allow them to see sexual content. Therefore, marketers should avoid sexual content in their advertisements.

Similarly, marketers should analyze the religiosity of their consumers. If the consumers are conservative and religious, marketers should not use any controversial content like sex or exaggeration in their advertisement.

There are some limitations of the research. The target population of the study was university students in Pakistan and the products were limited to Fast Moving Consumer Goods (FMCGs). Therefore, samples with different demographics should be used and products from different categories can also make further research more worthy. Future research can also explore the relationship between Islamic way of advertisement and brand recall and recognition, besides the attitudinal measurements. Finally, the research could be extended to other media use like magazines and social media.

\section{References}

Adas, A.B. (2006). The making of entrepreneurial Islam and the Islamic spirit of capitalism. Journal for Cultural Research, 10(2), 113-125.

Ahmad, N. (2018). Towards advancing debates on Islamic marketing: A renewed perspective. Journal of Islamic Marketing, 9(1), 152-166.

Akbari, M., Gholizadeh, M. H., \& Zomorrodi, M. (2018). Islamic symbols in food packaging and purchase intention of Muslim consumers. Journal of Islamic Marketing, 9(1), 117-131.

Allport, G. W. (1966). The religious context of prejudice. Journal for the Scientific Study of Religion, 5(1), 447-457.

Al-Makaty, S. S., Tubergen, V. G. N., Whitlow, S. S., \& Boyd, D. D. (1996). Attitudes toward advertising in Islam. Journal of Advertising Research, 36(2), 16-26. 
Al-Nashmi, M. M., \& Almamary, A. A. (2017). The relationship between Islamic marketing ethics and brand credibility: A case of pharmaceutical industry in Yemen. Journal of Islamic Marketing, 8(2), 261-288.

Alom, M. M., \& Haque, M. S. (2011). Marketing: An Islamic perspective. World Journal of Social Sciences, 1(3), 71-81

Alserhan, B. A. (2011). The principles of Islamic marketing. Farnham, England: Gower Publishing Limited.

Anand, C., \& Kumar, M. (1982). Developing a modernity attitude scale. Indian Educational Review, 17(3), 28-41.

Anwar, M., \& Saeed, M. (1996). Promotional tools of marketing: An Islamic perspective. Intellectual Discourse, 4(1-2), 15-30.

Armstrong, K. (2001). Battle for God: A history of fundamentalism. New York, NY: Ballantine Books.

Arnould, E., Price, L. \& Zikhan, G. (2004). Consumers (2 ${ }^{\text {nd }}$ ed.). New York, NY: McGraw-Hill.

Barton, K., \& Vaughan, G. (1976). Church membership and personality. Social Behaviour and Personality, $4(1), 11-16$.

Bashir, A., \& Malik, N.(2010). Effects of advertisement on consumer behavior of university students. Paper presented at $2^{\text {nd }} \mathrm{CBRC}$, Lahore. https://www.iiste.org/Journals/index.php/JMCR/article/viewFile/28299/29042

Charrad, M. (2001). States and women's rights: The making of postcolonial Tunisia, Algeria, and Morocco. University of California.

Cleveland, M., Laroche, M., \& Hallab, R. (2013). Globalization, culture, religion, and values: Comparing consumption patterns of Lebanese Muslims and Christians. Journal of Business Research, 66(8), 958-967.

Batra, R., \& Holbrook, M. B. (1990). Developing a typology of affective responses to advertising. Psychology and Marketing, 7(1), 11-25.

Batra, R., \& Ray, M. L. (1986). Situational effects of advertising repetition: The moderating influence of motivation, ability, and opportunity to respond. Journal of Consumer research, 12(4), 432-445.

Belch, G. E., \& Belch, M. A. (2004). Advertising and promotion: An integrated marketing communications perspective $\left(6^{\text {th }}\right.$ ed). New York: NY: McGraw-Hill.

Bin-Hasan,Z. (2016). From legalism to value-oriented Islamic finance practices. Humanomics, 32(4), $437-458$.

Blackwell, R. D., Miniard, P. W., \& Engel, J. F. (2001). Consumer behavior. Orlando, FL: Harcourt Inc.

Bukhari, M. (2009). Sahih al-Bukhari, trans. M.M. Khan, ed. M.al-Almany, Version: 0910112346244624-21. 
Burke, M. C., \& Edell, J. A. (1989).The impact of feelings on ad-based affect and cognition. Journal of Marketing Research, 26(1), 69-83.

Burke, M. C., \& Edell, J.A. (1986). Ad reactions over time: Capturing changes in the real world. Journal of Consumer Research, 13(6), 114-118.

Butt, M. M., Fam, K. S., \& Jong, H. Y.(2010). Attitude towards offensive advertising. Journal of Business Ethics, 32(2), 127-142.

Cohen, J., Cohen, P., West, S. G., \& Aiken, L. S. (1983). Applied multiple regression for the behavioral sciences. Hillsdale, NJ: Laurence Erlbaum.

DeBono, K. (1987). Investigating the social-adjustive and value- expressive functions of attitudes: Implications for persuasion process. Journal of Personality and Social Psychology, 52(2), 279-287.

DeJong, G. F., Faulkner, J. E., \& Warland, R.H. (1976). Dimensions of religiosity reconsidered: Evidence from a cross-cultural study. Study Forces, 54(6), 866-889.

Delener, N. (1994). Religious contrasts in consumer decision behavior patterns: Their dimensions and marketing implications. European Journal of Marketing, 28(5), 36-53.

Deng, S., Jivan, S., \& Hassan, M. L. (1994). Advertising in Malaysia: A cultural perspective. International Journal of Advertising, 13(2),153-166.

Dudley, M. G., \& Kosinski Jr, F. A. (1990). Religiosity and marital satisfaction: A research note. Review of Religious Research, 22, 78-86.

Dudley, S. C. (1999). Consumer attitudes toward nudity in advertising. Journal of Marketing Theory and Practice, 7(3), 89-96.

Edell, J. A., \& Burke, M. C. (1987). The power of feelings in understanding advertising effects. Journal of Consumer Research, 14(3),421-433.

El-Bassiouny, N. (2014). The one billion plus marginalization: Toward a scholarly understanding of Islamic consumers. Journal of Business Research, 67(2), 42-49.

Essoo, N., \& Dibb, S. (2004). Religious influences on shopping behaviour: An exploratory study. Journal of Marketing Management, 20(7/8), 683-712.

Fam, K.S., Waller, D.S. \& Erdogan, B.Z. (2004). The influence of religion on attitudes towards the advertising of controversial products. European Journal of Marketing, 38(5/6), 537-555.

Gardner, P. M. (1985). Does attitude toward the ad affect brand attitude under a brand evaluation set. Journal of Marketing Research, 22(2), 207-222.

Grossman, R. P., \& Till, B. D. (1998). The persistence of classically conditioned brand attitudes. Journal of Advertising, 27(1), 23-31.

Guiso, L., Sapienza, P., \& Zingales, L. (2003). People's opium? Religion and economic attitudes. Journal 
of Monetary Economics, 50(1), 225-282.

Hair, J. F., Anderson, R. E., Tatham, R. L. \& Black, W. C. (1998). Multivariate data analysis. Upper Saddle River, NJ: Prentice Hall International.

Hallett, M., \& Khoshbin, S. (1980). A physiological mechanism of bradykinesia. Brain, 103(2), 301-314.

Haque, A., Rahman, S., \& Haque, M. (2011). Religiosity, ethnocentrism and corporate image towards the perception of young Muslim consumers: Structural equation modelling approach. European Journal of Social Sciences, 23(1), 98-108.

Hawkins, D. I., Best, R. J. \& Coney, K. A. (2004). Consumer behavior: Building marketing strategy (9 $9^{\text {th }}$ ed.). New York, NY: McGraw-Hill, Inc.

Hirschman, E. C. (1983). Religious affiliation and consumption process: An initial paradigm. Journal of Research in Marketing, 6(1), 131-170.

Holbrook, M. B., \& Batra, R. (1987). Assessing the role of emotions as mediators of consumer responses to advertising. Journal of Consumer Research, 14(3),404-420.

Jayawardhena, C., \& Farrell, A.M. (2011). Effects of retail employees' behaviour on customers' service evaluation. International Journal of Retail EB Distribution Management, 39(3), 203- 217.

Jungyeon S. (2017). Effects of emotional advertisement between same and competitive brand on the attitude towards ad after consumer dissatisfaction. International Information Institute, 20(8), 6063-6070.

Katz, D. (1960). The functional approach to the study of attitudes. Public Opinion Quarterly, 24(2), 163-204.

Kavoossi, M., \& Frank, J. (1990). The language-culture interface in Persian Gulf States print advertisements: Implications for international marketing. Journal of International Consumer Research, 31(3), 5-25.

Khraim, H. (2010). Measuring religiosity in consumer research from Islamic perspective. International Journal of Marketing Studies, 2(2), 166-179.

Kim, S., David, S., \& Zafer, B. (2004). The influence of religion on attitudes towards the advertising of controversial products. European Journal of Marketing, 38(5/6), 537-555.

King, J. E., \& Crowther, M.R. (2004). The measurement of religiosity and spirituality: Examples and issues from psychology. Journal of Organizational Change Management, 17(1), 83-101.

KoKu, P. S. (2011). Natural market segment: Religion and identity-the case of Zongos in Ghana. Journal of Islamic Marketing,2(2).177-185.

Kotler, P., \& Keller, K. L. (2012). Marketing management (14 ${ }^{\text {th }}$ ed.). Essex, UK: Pearson Education Ltd.

LaBarbera, P. (1987). Consumer behavior and born again Christianity. Research in Consumer Behaviour, 2(1), 193-222. 
LaTour, M. S., \& Henthorne, T. L. (1994). Ethical judgments of sexual appeals in print advertising. Journal of Advertising, 23(3), 81-90.

Lipka, M. (2016). Muslims and Islam: Key findings in the U.S. and around the world. Retrieved from http://www.pewresearch.org/fact- tank/2016/07/22/muslims-and-islam-key-findingsin-the-u-sand-around-the-world/

Luqmani, M., Yavas, U., \& Quraeshi, Z. (1987). Advertising in Saudi Arabia: Content and Regulation. International Journal of Advertising, 6(1), 59-71.

Lutz, R. J. (1975).Changing brand attitudes through modification of cognitive structure. Journal of Consumer Research, 1(4), 49-59.

Machleit, K. A., \& Wilson, R. D. (1988). Emotional feelings and attitude toward the advertisement: The roles of brand familiarity and repetition. Journal of Advertising, 17(3), 27-35.

Maselko, J., Kubzansky, L. D., Kawachi, I., Staudenmayer, J., \& Berkman, L. (2006). Religious attendance and decline in pulmonary function in a high-functioning elderly cohort. Annals of Behavioral Medicine, 32(3), 245-53.

Matitila, A.S., Apostolopoulos, Y., Sonmez, S., Yu, L. \& Sasidharan, V. (2001). The impact of gender and religion on college student's spring break behavior, Journal of Travel Research, 40(2), 193-200.

Michell, P., \& Al-Mossawi, M. (1999). Religious commitment related to message contentiousness. International Journal of Advertising, 18(4), 427-443.

Muehling, D. D., \& Laczniak, R.N. (1988). Advertising's immediate and delayed influence on brand attitudes: Considerations across message involvement levels. Journal of Advertising, 17(4), 23-34.

Nasr, V. (2009). Brands, Islam and the new Muslim consumer. Journal of International Marketing, 1(1) 64-74.

Nunnally, J. C., \& Bernstein, I. H. (1994). Psychometric theory. New York, NY: McGraw-Hill.

Özlem, S. (2011). Researching Islamic marketing: Past and future perspectives. Journal of Islamic Marketing, 2(3), 246-258.

Pettinger, C., Holdsworth, M. \& Gerber, M. (2004). Psycho-social influences on food choice in Southern France and Central England. Appetite, 42(3), 307-316.

Rehman, A.U., \& Shabbir, M.S. (2010).The relationship between religiosity and new product adoption. Journal of Islamic Marketing, 1(1), 63-69.

Rehman, S. N., \& Brooks Jr, J. R. (1987). Attitudes toward television advertisements for controversial products. Marketing Health Services, 7(3), 78-83.

Rice, G., \& Al-Mossawi, M. (2002). The implications of Islam for advertising messages: The Middle Eastern context. Journal of Euro marketing, 11(3), 71-96.

Run, E. C. D., Butt, M. M., Fam, K.-S., \& Jong, H. Y. (2010). Attitudes towards offensive advertising: 
Malaysian Muslims' views. Journal of Islamic Marketing, 1(1), 25-36.

Saeed, M., Ahmad, Z.U. \& Mukhtar, S.M. (2001). International marketing ethics from an Islamic perspectives: A value maximization approach. Journal of Business Ethics, 3(2), 127-142.

Sallam, H., \& Hanafy, A.A. (1988). Employee and employer: Islamic perception. Retrieved from: https:// link.springer.com/content/pdf/10.1023/A:1005711414306.pdf

Samir, A. (2012). Islamic marketing: addressing the Muslim market. An - Najah University Journal of Research, 26(6), 210-230.

Sandikcı, O., \& Ger, G. (2010). Veiling in style: how does a stigmatized practice become fashionable? Journal of Consumer Research, 37(1), 15-36.

Schiffman, L., \& Kanuk, L. (2000).Consumer behavior ( $7^{\text {th }}$ ed.). New York, NY: Prentice Hall.

Schwab, R. \& Peterson, K.U. (1980). Religiousness: Its relation to loneliness, neuroticism and subjective wellbeing. Journal for the Scientific Study of Religion, 29(3), 335-345.

Sedgwick, M. J. (2006). Islam E⿱ Muslims: A guide to diverse experience in a modern world. Boston, MA: Intercultural Press.

Shafiq, A., Haque, A., Abdullah, K., \& Jan, M. T. (2017). Beliefs about Islamic advertising: An exploratory study in Malaysia. Journal of Islamic Marketing, 8(3), 409-429.

Shavitt, S., Lowry, T. M., \& Han, S. (1992). Attitude functions in advertising: The interactive role of product and self-monitoring. Journal of Consumer Psychology, 1(1), 337-364.

Sheth, E.C. (1974). Models of buyer behavior: Conceptual and empirical. New York, NY:Haroer and Row.

Shin, J., Park, M., Moon, M., \& Kim, M. (2010). Does religiosity affect consumer's socialization agent and shopping orientation? Paper Presented at the International Conference on E-business, Management and Economics. http://www.ipedr.com/vol3/32-M00050.pdf

ShyanFam, K., Waller, D. S., \& Zafer Erdogan, B. (2004). The influence of religion on attitudes towards the advertising of controversial products. European Journal of Marketing, 38(5/6), 537-555.

Siddiqi, M.N. (2008). Emergence of ethical investment. New Delhi: Institute of Objective Studies.

Simpson, P. M., Brown, G., \& Widing, R. E, I. I. (1998). The association of ethical judgment of advertising and selected advertising effectiveness response variables. Journal of Business Ethics, 17(2), 125-136.

Swanson, L. A. (1996). 1.19850 + billion mouths to feed: food linguistics and cross-cultural, cross-national food consumption habits in China. British Food Journal, 98(6), 33-44.

Tariq, M., \& Khan, M. A. (2017). Offensive advertising: A religion based Indian study. Journal of Islamic Marketing, 8(4), 656-668.

Thyne, M., Lawson, R., \& Todd, S. (2006). The use of conjoint analysis to assess the impact of the 
cross-cultural exchange between hosts and guests. Tourism Management, 27(2), 201-213.

Waller, D. S. \& Fam, K.S. (2000). Cultural values and advertising in Malaysia: Views from the Industry. Asia Pacilc Journal of Marketing and Logistics,12(1), 3-16.

Waller, D. S. (1999). Attitudes towards offensive advertising: an Australian study. Journal of Consumer Marketing, 16(3), 288-94.

Wiebe, K. F. \& Fleck, J. R. (1980). Personality correlates of intrinsic, extrinsic \& nonreligious orientations. Journal of Psychiatry, 105(1), 111-117.

Wilcox, K., Kim H. M., \& Sen, S. (2009). Why do consumers buy counterfeit luxury brands? Journal of Marketing Research, 46(1), 247-259.

Wilkes, R., Burnett, J. \& Howell, R. (1986). On the meaning and measurement of religiosity in consumer research. Journal of the Academy of Marketing Science, 14(1), 47-56.

Yong, A. G., \& Pearce, S. (2013). A beginner's guide to factor analysis: Focusing on exploratory factor analysis. Tutorials in Quantitative Methods for Psychology, 9(2), 79-94.

Zakaria, N., \& Abdul-Talib, A. N. (2010). Applying Islamic market-oriented cultural model to sensitize strategies towards global customers, competitors, and environment. Journal of Islamic Marketing, 1(1), $51-62$.

Zamani-Farahani, H., \& Musa, G. (2012). The relationship between Islamic religiosity and residents' perceptions of socio-cultural impacts of tourism in Iran: Case studies of Sare'in and Masooleh. Tourism Management, 33(4), 802-814.

Zebal, M. A. (2018). The impact of internal and external market orientation on the performance of non-conventional Islamic financial institutions. Journal of Islamic Marketing, 9(1), 132-151. 


\section{Appendices}

Appendix 1: Reliability of Measurement Scale Items

\begin{tabular}{|c|c|c|}
\hline Measuring Scale Items & No of Items & Reliability Cronbach's alpha Value \\
\hline Religiosity & 16 & 0.728 \\
\hline Attitude towards advertisement & 4 & 0.795 \\
\hline Attitude towards brand & 3 & 0.801 \\
\hline Purchase intention & 3 & 0.80 \\
\hline
\end{tabular}

Appendix 2: Exploratory factor analysis matrix

\begin{tabular}{|c|c|c|c|c|}
\hline Scale Items & REL & ATTIAD & ATTIBRAND & PI \\
\hline REL1 & .734 & 0.044 & -0.07 & 0.028 \\
\hline REL2 & .829 & 0.009 & -0.004 & -0.03 \\
\hline REL3 & .825 & -0.019 & -0.04 & -0.029 \\
\hline REL4 & .737 & 0.023 & 0.149 & -0.092 \\
\hline REL5 & .892 & 0.285 & 0.047 & -0.030 \\
\hline REL6 & .647 & -0.030 & 0.028 & -0.083 \\
\hline REL7 & .718 & -0.018 & 0.082 & 0.293 \\
\hline REL8 & .635 & 0.015 & -0.062 & 0.198 \\
\hline REL9 & .517 & -0.083 & -0.023 & -0.020 \\
\hline REL10 & .638 & 0.016 & -0.098 & -0.024 \\
\hline REL11 & .744 & 0.192 & 0.025 & -0.071 \\
\hline REL12 & .636 & 0.037 & -0.101 & 0.094 \\
\hline REL13 & .788 & 0.098 & -0.134 & -0.047 \\
\hline REL14 & .618 & -0.184 & 0.009 & -0.018 \\
\hline REL15 & .732 & -0.014 & -0.113 & -0.139 \\
\hline REL16 & .714 & -0.168 & -0.04 & 0.048 \\
\hline ATTIAD1 & -.054 & .783 & -0.014 & 0.077 \\
\hline ATTIAD2 & -.074 & .638 & -0.032 & 0.139 \\
\hline ATTIAD3 & -.106 & .796 & -0.106 & -0.087 \\
\hline ATTIAD4 & .058 & .654 & -0.237 & 0.043 \\
\hline ATTIBRAND1 & -.067 & 0.084 & 0.835 & 0.073 \\
\hline ATTIBRAND2 & -.040 & 0.046 & 0.739 & 0.013 \\
\hline
\end{tabular}




\begin{tabular}{|c|c|c|c|c|}
\hline ATTIBRAND3 & -.042 & -0.023 & 0.729 & -0.014 \\
\hline PI1 & .193 & 0.030 & 0.09 & 0.697 \\
\hline PI2 & -0.135 & 0.138 & 0.005 & 0.774 \\
\hline PI3 & 0.145 & 0.137 & -0.132 & 0.826 \\
\hline
\end{tabular}

Appendix 3: Factor correlational matrix

\begin{tabular}{|c|c|c|c|c|}
\hline Scale Items & REL & ATTIAD & ATTI BRAND & PI \\
\hline REL & .775 & & & \\
\hline ATTIAD & .108 & .797 & & \\
\hline ATTIBRAND & .098 & -.112 & .797 & \\
\hline PI & .035 &. .181 & .010 & .806 \\
\hline
\end{tabular}


